\title{
REKLAMASI PESISIR KOTA CIREBON
}

\author{
WIYOGA TRIHARTO \\ Program Studi Teknik Arsitektur \\ Universitas Indraprasta PGRI \\ Jl. Nangka No. 58 C Tanjung Barat, Jagakarsa, Jakarta 12530 \\ Email: wiyogatriharto@yahoo.com
}

\begin{abstract}
Abstrak. Penataan pesisir Kota Cirebon yang berkelanjutan berguna untuk menumbuhkan perekonomian wilayah pesisir. Dengan reklamasi, luas wilayah Kecamatan Kejaksan dan Lemahwungkuk akan bertambah sehingga di atas tanah reklamasi tersebut dapat dibangun waterfront city untuk meningkatkan potensi pesisir Kota Cirebon. Waterfront city meliputi objek wisata, perdagangan, permukiman dan sentra perekonomian lainya. Metode analisis data yang digunakan adalah (1) Analisis Fisik Lingkungan, ; (2) Analisis Sirkulasi dan Aksesibilitas; (3) Analisis Fasilitas; dan, (4) Analisis Pariwisata. . Kesimpulannya adalah Kota Cirebon mengalami beberapa permasalahan seperti: persebaran penduduk yang belum merata, potensi SDA (sumber daya alam) yang belum berkembang, kondisi pesisir pantai yang mengalami abrasi dan sendimentasi, dan minimnya prasarana dan sarana penunjang. Berdasarkan keterbatasan itu, penulis berargumentasi bahwa pembangunan kawasan tepi air/waterfront city yang berkelanjutan dapat dilakukan untuk memperbaiki kondisi di kawasan pesisir ini.
\end{abstract}

Kata Kunci: Reklamasi, Waterfront City, bekelanjutan

Abstract. Sustainable planning of coastal areas of Kota Cirebon is meant to enable the economic growth within the areas. By doing reclamation, the space of the Kecamatan Kejaksan and Lemahwungkuk will be wider and can be used to build the waterfront city in order to increase the economic growth. In this article, the writer argues that the waterfront city can be built upon the artificial land (the reclamation area). The methods used in this research are (1) physical environment analysis; (2) circulation and accessibility analysis; (3) facilities analysis; and, (4) tourism analysis. The writer concludes that Kota Cirebon has several problems, such as, population distribution, undeveloped natural resources, the abrasion and sedimentation of the coastal areas, the lack of facilities and infrastructure.

Keywords: Reclamation, Waterfront City, sustainable

\section{PENDAHULUAN}

Kawasan pesisir merupakan kawasan yang sangat sentral dan penting dalam suatu wilayah. Di sisi lain, kawasan ini juga berpotensi mengalami berbagai gangguan, misalnya komodifikasi ruang. Komodifikasi area pesisir oleh pihak-pihak tertentu dengan tujuan mengapitalisasi modal membuat area ini rentan berubah secara spasial. Wujud komodifikasi itu, misalnya, membangun kawasan hunian baru (perumahan), infrastruktur transportasi, kawasan industri, mendirikan pelabuhan, mencetak lahan pertanian, melakukan budidaya tambak, dan industri pariwisata.

Berdasarkan UU No. 27 Tahun 2007 Republik Indonesia, wilayah pesisir didefinisikan sebagai daerah peralihan antara ekosistem laut dan darat yang dipengaruhi oleh perubahan di laut dan darat. Wilayah pesisir memerlukan pengelolaan yang berkelanjutan untuk meningkatkan nilai ekonomi, sosial, dan budaya masyarakat melalui peran serta masyarakat dalam memanfaatkan sumber daya pesisir dan pulau-pulau kecil. Pengelolaan 
wilayah pesisir meliputi pemanfaatan, perencanaan, pengendalian, dan pengawasan terhadap interaksi manusia dalam memanfaatkan sumber daya pesisir dan lautan.

Pembangunan kawasan pesisir harus mengacu pada prinsip keberkelanjutan agar tidak terjadi kerusakan lingkungan. Pembangunan kawasan pesisir yang berkelanjutan dapat dilakukan dengan cara reklamasi pantai (memperluas wilayah pesisir), minapolitan, pembangunan waterfront city, dan lain lain-lain. Pengelolaan wilayah pesisir berkelanjutan membutuhkan penataan yang terintegrasi dan terpadu dengan memenuhi berbagai fasilitas penunjang prasarana dan sarana di kawasan pesisir tersebut. Keterbatasan wilayah pesisir membuat perluasan area menjadi tidak terhindarkan. Salah satu cara memperluas area dapat dilakukan dengan menerapkan reklamasi. Tentu saja, penerapan reklamasi tersebut harus mempertimbangkan unsur abrasi dan sedimentasi area pesisir. Di artikel ini, penulis berargumentasi bahwa waterfront city dapat dibangun di atas lahan/tanah reklamasi. Pembangunan tersebut dapat dimanfaatkan untuk lahan pariwisata, perdagangan, sentral perekonomian permukiman, perkantoran, atau minapolitan.

Kondisi geografi Kota Cirebon merupakan dataran rendah dengan kondisi pesisir memiliki banyak potensi yang perlu dikembangkan untuk menumbuhkan perekonomian. Kawasan pesisir tersebut sangatlah dekat dengan pusat kota. Potensi pesisir kota Cirebon dapat ditingkatkan dengan membangun waterfront city yang dapat menjadi pintu masuk kedua dari laut setelah pintu pertama dari darat. Pembangunan waterfront city dapat mengatasi permasalahan keterbatasan wilayah yang kecil sebagai perluasan wiayah Kota Cirebon yang sedang berkembang sekaligus memperbaiki kerusakan pantai akibat abrasi.

Reklamasi pesisir Kota Cirebon telah dilakukan untuk perluasan kawasan pelabuhan Cirebon, untuk itu wilayah pesisir sangatlah dibutuhkan sebagai penunjang prasarana dan sarana pelabuhan. Pembangunan waterfront city dengan reklamasi adalah untuk penunjang pelabuhan juga memperbaiki kondisi kawasan pesisir dan menjaga agar tetap baik. Selain itu dapat meningkatkan sektor perikanan dan kelautan yang memiliki potensi sangat besar dalam hal budidaya tambak serta pengolahan hasil laut, juga dapat meningkatkan penghasilan petambak dan nelayan.

\section{METODE}

\section{Metode Data Sekunder}

Data sekunder merupakan data yang diperoleh melalui instansi yang terkait melalui survey. Pengumpulan data sekunder dilakukan dengan teknik dokumentasi, yaitu pengumpulan / perekaman data yang berasal dari data - data sekunder yang berupa buku publikasi instansi pemerintah daerah Kota Cirebon, swasta maupun masyarakat yang ada kaitannya dengan permasalahan pada penelitian ini sebagai bahan masukan dalam proses analisis.

\section{Metode Analisis Data}

4 tahapan metode analisis data, berikut adalah 4 tahap metode analisis dalam studi ini.

\section{Tahap 1 : Analisis Fisik Lingkungan}

Tahap ini kajian dilakukan dalam upaya mendapatkan struktur pola ruang dikawasan pesisir yang terkait pengembangan, potensi serta permasalahan pada kawasan pesisir.

\section{Tahap 2 : Analisis Sirkulasi dan Aksesibilitas}

Tahap ini kajian dilakukan dalam upaya mengetahui mobilisasi dan transportasi baik darat dan laut menuju objek wisata, hingga didapat hasil kesimpulan potensi aksebilitas menuju objek wisata.

\section{Tahap 3 : Analisis Fasilitas}

Tahap ini mengkaji untuk mengetahui kondisi saat ini yang terkait dengan fasilitas penunjang baik itu permukiman penduduk maupun objek wisata dan sekitarnya, yang berkait akan fasilitas sesuai kebutuhannya berdasarkan kegiatan. 
Tahap 4 : Analisis Pariwisata

Tahap ini mengkaji potensi sektor wisata yang dapat dikembangkan dan menarik wisatawan lokal dan manca negara, beserta kendala dalam pengembangnya.

\section{Alur Pemikiran Reklamasi Pesisir Kota Cirebon}

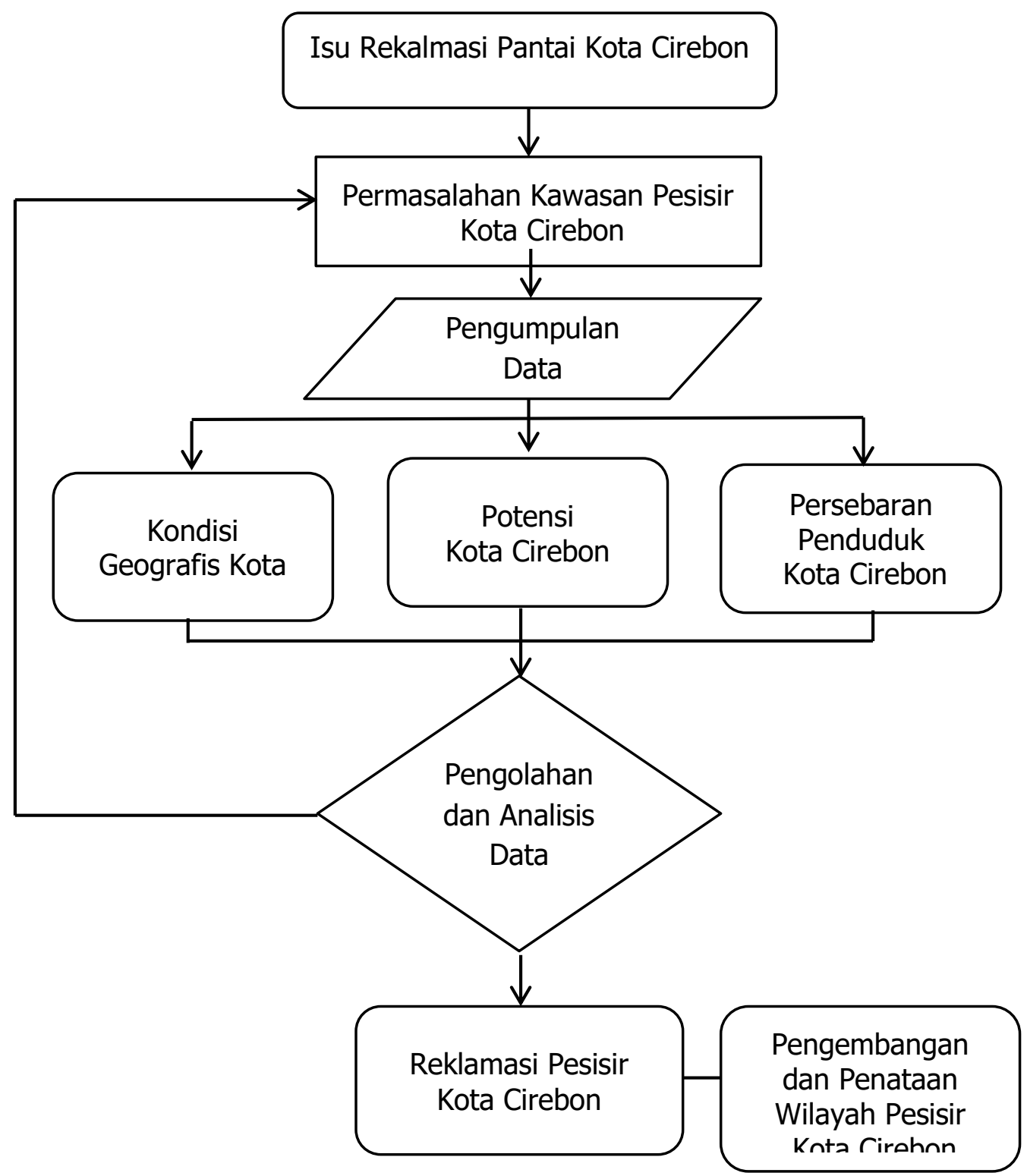

\section{HASIL DAN PEMBAHASAN}

\section{Lokasi Penelitian}

Wilayah penelitian berlokasi di kota Cirebon. Kota Cirebon memiliki posisi dengan letak geografis sangat strategis yang merupakan salah satu jalur pesisir utama dalam transportasi laut dari Jakarta menuju Jawa Barat dan Jawa Tengah pantai utara. Luas wilayah keseluruhan kota Cirebon 3.736,8 hektar. Berikut gambar pesisir kota Cirebon : 


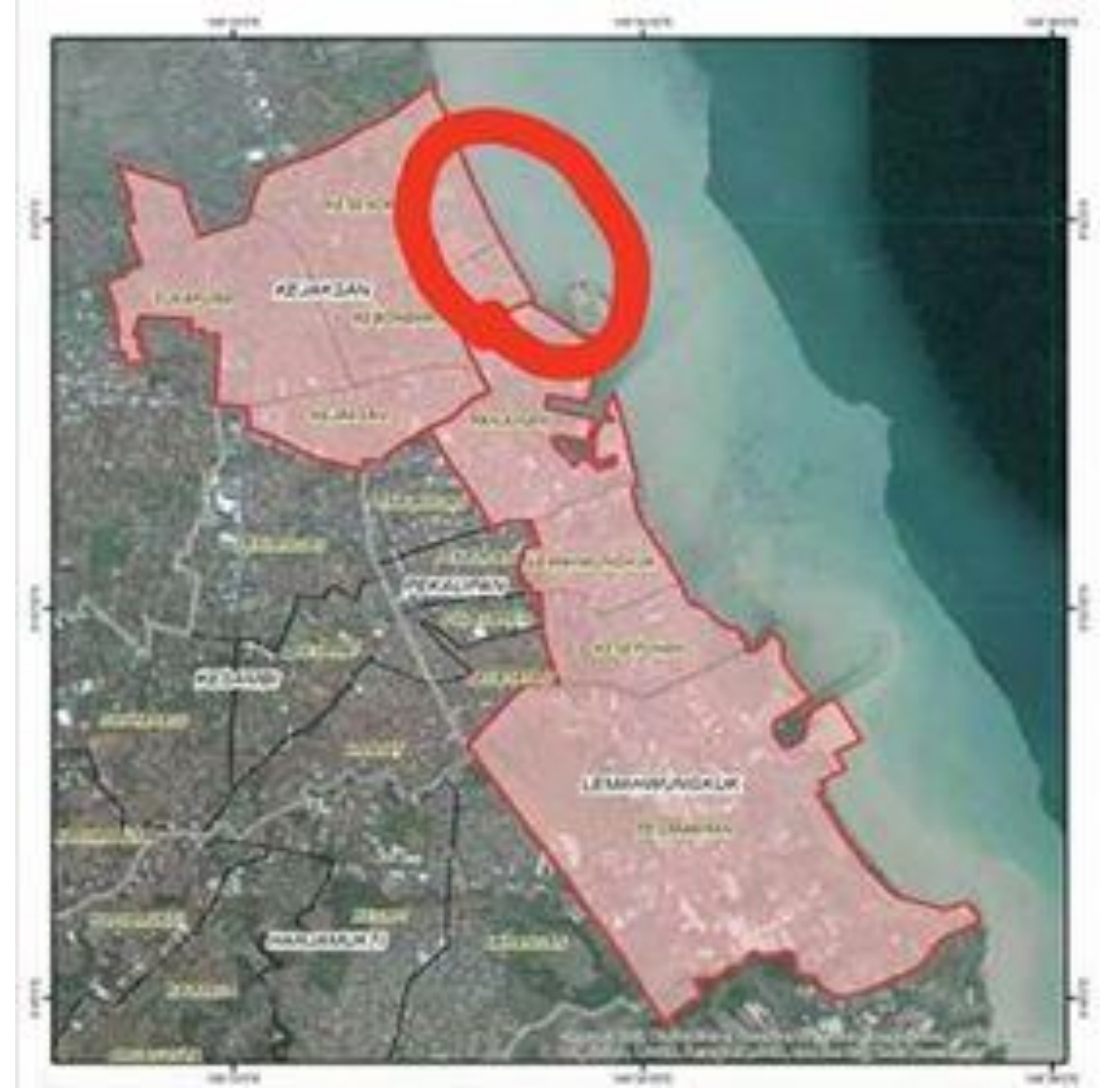

Gambar 1. Pesisir Kota Cirebon, Kecamatan Kejaksan dan Lemahwungkuk Sumber: Google Earth, 2018

\section{Analisis Lokasi Penelitian}

Kota Cirebon merupakan Provinsi Jawa Barat, kota ini terletak di utara pantai Pulau Jawa. Kota Cirebon memiliki letak geografis $108,33^{\circ}$ dan $6,41^{\circ}$ Lintang Selatan pantai utara Pulau Jawa. Kota Cirebon berbatasan dengan Sungai Banjir Kanal atau kabupaten Cirebon di sebelah barat, Sungai Kalijaga di sebelah selatan, Sungai Kedung Pane di sebelah utara, dan Laut Jawa di sebelah timur.

Kota beriklim tropis, memiliki 5 kecamatan yang terdiri dari, yaitu kecamatan Pekalipan, Kesambi, Lemahwungkuk, Harjamukti, dan Kejaksan.

Kepadatan penduduk belum tersebar merata pada setiap kecamatan. Berikut data luas wilayah, penduduk, dan kepadatan penduduk per kilometer persegi tahun 2015. 
Tabel 1. Luas Wilayah, Penduduk, dan Kepadatan Penduduk Per Kilometer Persegi Menurut Kecamatan Tahun 2015

\begin{tabular}{|c|l|c|c|c|}
\hline No. & \multicolumn{1}{|c|}{ Kecamatan } & $\begin{array}{c}\text { Luas Wilayah } \\
\left(\mathbf{K m}^{\mathbf{2}}\right)\end{array}$ & $\begin{array}{c}\text { Penduduk } \\
(\text { Jiwa })\end{array}$ & $\begin{array}{c}\text { Pendatan } \\
\mathbf{K m}^{\mathbf{2}}\end{array}$ \\
\hline 1. & Harjamukti & 17,62 & 105,987 & 6.015 \\
\hline 2. & Lemahwungkuk & 6,51 & 54.788 & 8.415 \\
\hline 3. & Pekalipan & 1,56 & 30.013 & 19.239 \\
\hline 4. & Kesambi & 8,06 & 72.819 & 9.034 \\
\hline 5. & Kejaksan & 3,62 & 43.887 & 12.123 \\
\hline & Jumlah : 2015 & 37,36 & 307.494 & 8.230 \\
\hline & 2014 & 37,36 & 306.434 & 8.202 \\
\hline
\end{tabular}

Sumber: BPS Kota Cirebon

Permasalahan Kota Cirebon adalah wilayah administrasi yang terbatas/kecil yaitu 37,36 $\mathrm{km}^{2}$ atau 3.736,8 hektar. Pemerintah kota Cirebon menilai luas wilayah yang terbatas/kecil itu tidak dapat memenuhi pertumbuhan di kawasan pesisir kota Cirebon yang merupakan salah satu kawasan perluasan dari Kota Cirebon sendiri yang semakin berkembang. Persebaran penduduk di kota Cirebon juga tidak merata terutama pada kawasan pesisir pantai. Berdasarkan tabel 1, kepadatan penduduk di wilayah pesisir atau di kecamatan Pekalipan memilki kepadatan paling tinggi disbanding kecamatan Lemahwungkuk yang memiliki kepadatan paling rendah.

Geografi kota Cirebon mempengaruhi pola struktur kota Cirebon (Kusliansyah, Y. Karyadi, 2012-2013). Permasalahan pantai utara kota Cirebon adalah rentan mengalami abrasi dari ombak laut. Kota Cirebon memiliki empat sungai yang tersebar, yaitu Sungai Sukalila, Sungai Kedung Pane, Sungai Kalijaga, dan Sungai Kesunean (Kriyan). Sungai Kesunean sebelah selatan dipengaruhi oleh pasang surut air laut dan sungai Sukalila sebelah utara.

Kondisi pesisir kota Cirebon memburuk akibat adanya abrasi, dan sendimentasi (tanah timbul) baik dari sungai maupun akibat pembuangan sampah yang dilakukan masyarakat sekitar, sehingga pesisir pantai tidak layak lagi untuk dijadikan tempat wisata. Beberapa solusi permasalah perlu untuk dilakukan guna memperbaiki kembali kondisi lingkungan kawasan pesisir. Berikut gambaran kondisi di pesisir kota Cirebon : 
Faktor Exacta 11 (4): 385-398, 2018

p-ISSN: 1979-276X

e- ISSN: 2502-339X

DOI : $10.30998 /$ faktorexacta.v11i4.2974

Triharto-Reklamasi Pesisir Kota Cirebon.....
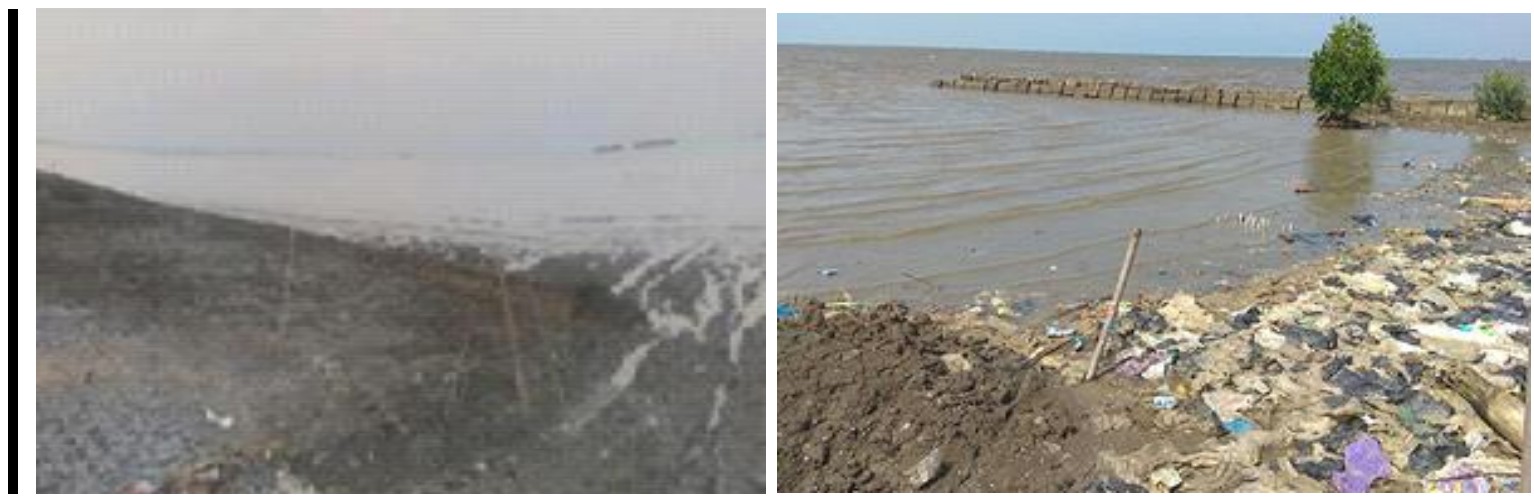

Gambar 2. Kondisi Pesisir Pantai Utara Cirebon

Sumber: Google Earth, 2018

Kota Cirebon begitu banyak memiliki potensi dapat dikembangkan. Letak kestrategisan merupakan potensi yang sangat besar membuat kota Cirebon mudah diakses dari Jakarta dengan jarak tempuh yang singkat melalui tol cipali. Potensi dalam bidang sejarah dengan peninggalannya seperti keraton kasepuhan dan keraton kaoman serta makam sunan menjadi daya tarik bagi kota Cirebon. Selain itu, potensi dalam bidang kuliner terdapat pula sumber daya manusia, dan sumber daya alam.

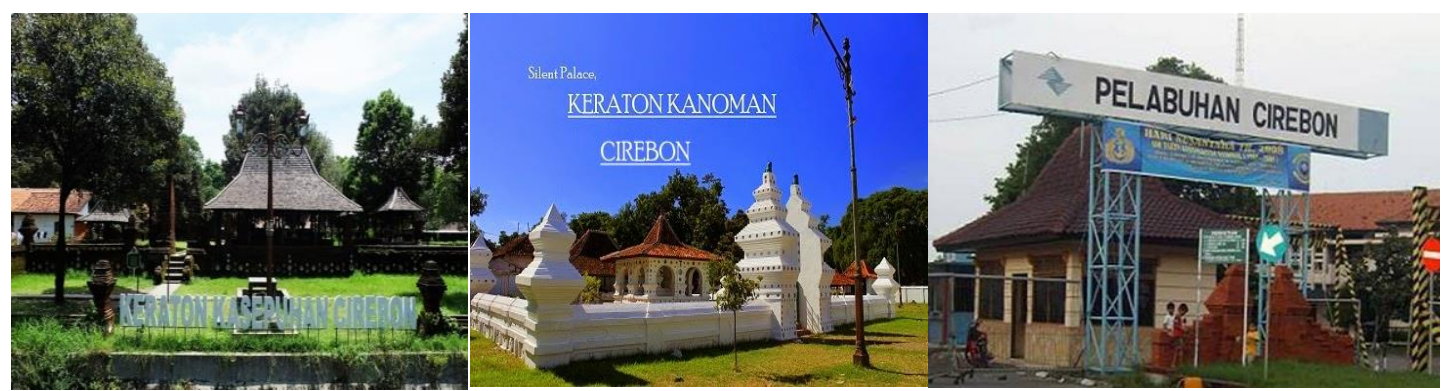

Keraton Kasepuhan

Keraton Kanoman

Pelabuhan Cirebon

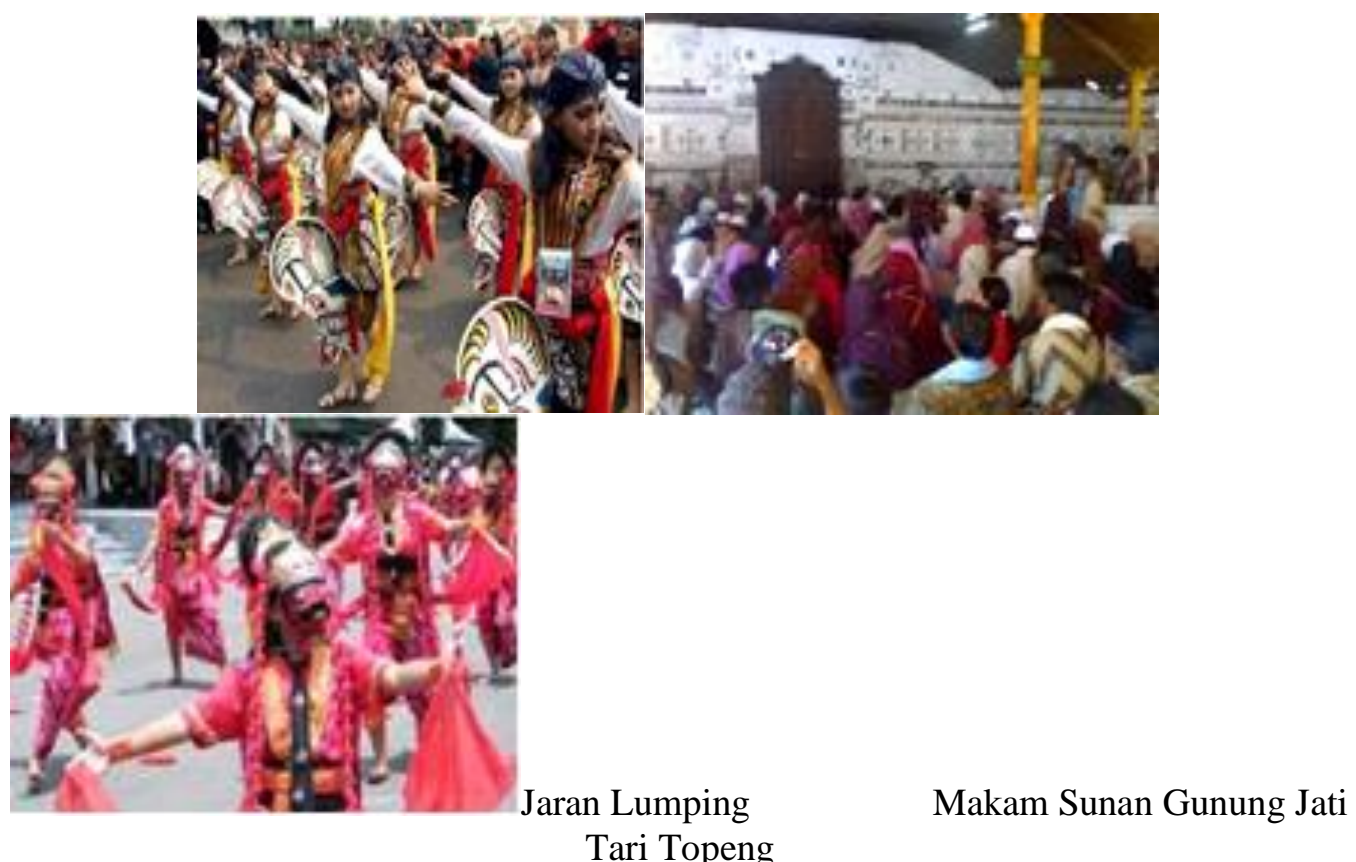


Gambar 3. Potensi Kota Cirebon

Potensi perikanan dan kelautan kota Cirebon juga dapat dikembangkan dan menjadi komoditi unggulan. Terlebih lagi kota Cirebon memiliki garis pantai mencapai 7,2 kilometer. Potensi tersebut terutama pada komoditas perairan laut dan budidaya tambak.

Tabel 2. Potensi Perikanan dan Kelautan Kota Cirebon tahun 2016

\begin{tabular}{|c|l|r|r|}
\hline No. & \multicolumn{1}{|c|}{ Komoditas } & $\begin{array}{c}\text { Produksi } \\
\text { (Ton) }\end{array}$ & $\begin{array}{c}\text { Nilai Produksi } \\
\text { (Ribu Rupiah) }\end{array}$ \\
\hline 1. & Perairan Laut & 3511,00 & 34314187,00 \\
\hline 2. & Perairan Umum & 8,00 & 51254,00 \\
\hline 3. & Budidaya Kolam & 92,00 & 825720,00 \\
\hline 4. & Budidaya Laut & 9,00 & 13125,00 \\
\hline 5. & Budidaya Tambak & 65,00 & 1135950,00 \\
\hline
\end{tabular}

Sumber: hasil survey, 2016

Budidaya tambak memiliki potensi yang besar, terutama udang karena permintaan ekspor udang meningkat tiap tahun. Perikanan dan kelautan memiliki potensi sangat terbesar di perairan Kota Cirebon, terutama komodititas ikan yang terbanyak. Potensi ikan laut tangkapan untuk wilayah pesisir kota Cirebon mencapai total 7.014.000 ton per tahunnya, menurut Dinas Perikanan Propinsi Jawa Barat.

Pelabuhan Kota Cirebon terletak pada kecamatan Lemahwungkuk. Keberadaan pelabuhan membuka akses Kota Cirebon dari luar. Pelabuhan Cirebon juga memiliki sejarah dengan terdapat permukiman kampung nelayan. Kampung Nelayan berada dekat Sungai Sukalila yang merupakan zona permukiman guna menunjang segala aktivitas pelabuhan.

Aksesibilitas menuju pesisir kota Cirebon juga mengandalkan beradaan Pelabuhan Cirebon tersebut. Optimalisasi pada Pelabuhan Cirebon akan meningkatkan segala aktivitas dalam pelabuhan. Dukungan infrastruktur yang memadai dalam pelabuhan serta prasarana dan sarana sekitar pelabuhan dapat meningkatkan aktivitas di pesisir kota Cirebon.

Potensi pariwisata kota Cirebon memiliki daya tarik tersendiri. Taman Ade Irma Suryani adalah salah satu pariwisata di daerah pesisir Cirebon yang dahulu dinamakan Traffic Garden Cirebon. Pembangkitan kembali tempat-tempat pariwisata di pesisir Cirebon dapat memberi nilai tambah serta meningkatkan perekonomi masyarakat disekitar wilayah pesisir Kota Cirebon.

\section{Pembahasan Lokasi Penelitian}

Dari analisis didapat dan menunjukkan bahwa kota Cirebon membutuhkan perluasan wilayah. Hal ini dilakukan untuk menunjang pemenuhan kebutuhan kota Cirebon yang terus semakin berkembang sebagai kota tujuan wisata dan tidak lagi sebagai kota perlintasan. Kota Cirebon sendiri memiliki pelabuhan yang digunakan untuk sarana transportasi barang dan orang antar pulau. Seiring berkembangnya Kota Cirebon menjadi daerah tujuan dan kecilnya Administrasi Kota Cirebon maka diperlukan perluasan wilayah kearah pantai disisi lain wilayah pantai bisa dijadikan pintu masuk ke Kota Cirebon, selain jalan darat mengingat 
potensi pelabuhan yang ada pada saat ini. Perluasan wilayah administrasi merupakan salah satu alternatif pilihan dengan cara melakukan reklamasi pantai, hal ini dilakukan karena kondisi pesisir pantai yang rusak oleh abrasi dan sendimentasi.

Perluasan wilayah administrasi di kawasan pesisir direncanakan pada kecamatan Kejaksan dan Lemahwungkuk seluas \pm 205 hektar. Pembangunan pada tepian laut pesisir pantai merupakan pembangunan yang berkelanjutan,. Waterfront city yang akan dibangun pada lahan/tanah reklamasi tersebut perlu memperhatikan tata-ruang kota dalam perencanaan pembangunanya. Sehingga dalam pembangunannya memenuhi tujuan yang akan dicapai, yakni menumbuh kembangkan dan meningkatkan potensi yang ada di pesisir kota Cirebon yang berkelanjutan.

Dalam perencanaan pembangunan perlu memperhatikan kondisi di sekitar pesisir pantai terutama gelombang laut, serta pola sedimentasi yang terjadi dan berbagai hal lainnya, guna melindungi pantai dengan cara memberikan pemecah gelombang lepas pantai yang akan dibangun waterfront city.

Pemecah gelombang atau biasa disebut breakwater merupakan sebuah bagunan yang digunakan untuk melindungi daerah perairan di pelabuhan dari gangguan gelombang. Bangunan ini memisahkan daerah perairan dengan laut lepas, sehingga perairan di pelabuhan tidak banyak dipengaruhi oleh gelombang besar di laut tersebut. Daerah perairan akan dihubungkan dengan laut oleh mulut pelabuhan dengan lebar tertentu dimana kapal keluar masuk melalui celah tersebut.

Sebenarnya pemecah gelombang atau breakwater dibedakan menjadi dua macam yaitu pemecah gelombang "lepas pantai" dan "sambung pantai". Tipe pertama untuk perlindungan pantai terhadap erosi sedangkan tipe kedua banyak digunakan pada perlindungan perairan pelabuhan. Umumnya kondisi perencanaan kedua tipe adalah sama, hanya pada tipe kedua perlu ditinjau karakteristik gelombang di beberapa lokasi di sepanjang pemecah gelombang, seperti halnya pada perencanaan jetty.

Breakwater atau pemecah gelombang lepas pantai adalah bangunan yang dibuat sejajar pantai dan berada pada jarak tertentu dari garis pantai. Breakwater atau Pemecah gelombang dibangun salah satu bentuk perlindungan pantai terhadap erosi atau abrasi dengan menghancurkan energi gelombang terlebih dahulu sebelum sampai ke pantai, sehingga akan terjadi endapan dibelakang bangunan. Endapan ini akan menghalangi transport sedimen sepanjang pantai.

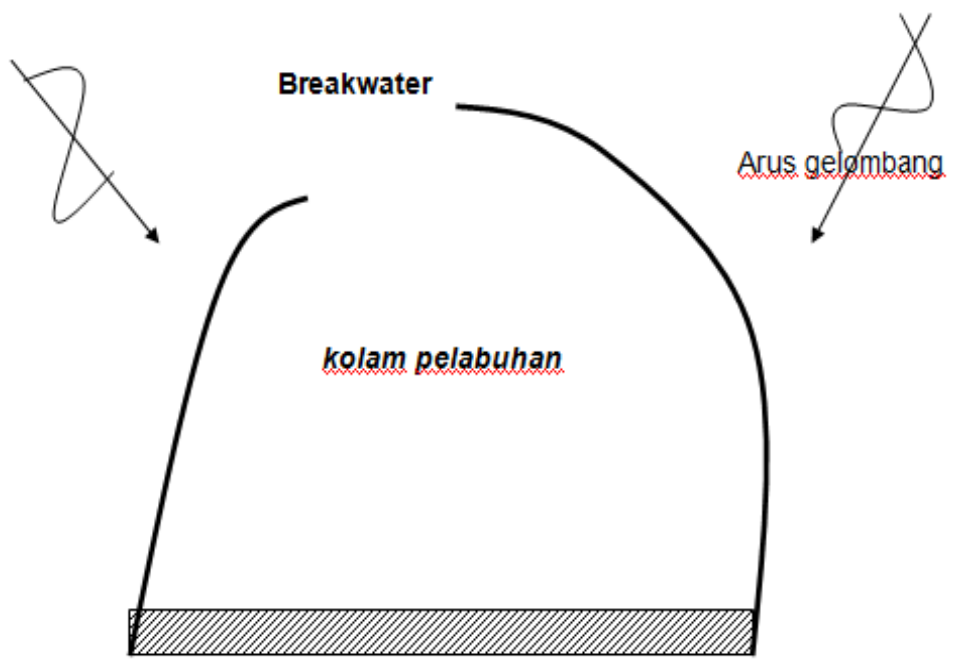

Gambar 4. Ilustrasi pelindung Breakwater Pada Areal Pelabuhan 
Pengertian Jetty adalah salah satu bangunan pelindung pantai yang dibangun tegak lurus di pantai dan diletakkan di kedua sisi pada muara sungai yang menuju ke laut. Jetty berfungsi mengurangi terjadinya pendangkalan pada alur akibat oleh sedimen yang terbawa arus sampai ke garis pantai. Pendangkalan akibat terjadinya sedimentasi dapat mengganggu lalu lintas kapal yang lewat di alur pelayaran tersebut

Untuk wilayah muara sungai yang biasa digunakan sebagai tempat bersandar atau berlabuhnya kapal-kapal nelayan pun perlu diberi perlindungan yaitu dengan membangun jetty agar tidak terjadi sedimentasi. Penggunaan muara sungai untuk tempat bersandar atau berlabuh kapal-kapal sebagai alur pelayaran akan terjadi pengendapan di muara dapat mengganggu lalu lintas kapal. Untuk keperluan tersebut jetty didesain harus panjang hingga ujungnya berada di luar gelombang pecah. Panjangnya Jetty akan membuat transport sedimentasi sepanjang pantai dapat ditahan, memungkinkan kapal masuk ke muara sungai karena gelombang pada alur pelayaran tidak pecah.

Pembangunan jetty sebagai pemecah gelombang dapat melindungi kawasan reklamasi pantai yang didirikan waterfront city. Hal ini juga mengurangi terjadinya abrasi pada kawasan reklamasi tersebut. Dengan terlindungi kawasan reklamasi, maka tahap selanjutnya perencanaan dengan menata kota baru di waterfront city atau tepi laut. Berikut adalah layout pembangunan waterfront city atau tepi laut di pesisir pantai Kota Cirebon. 
Faktor Exacta 11 (4): 385-398, 2018

p-ISSN: 1979-276X

e- ISSN: 2502-339X

Triharto-Reklamasi Pesisir Kota Cirebon.....

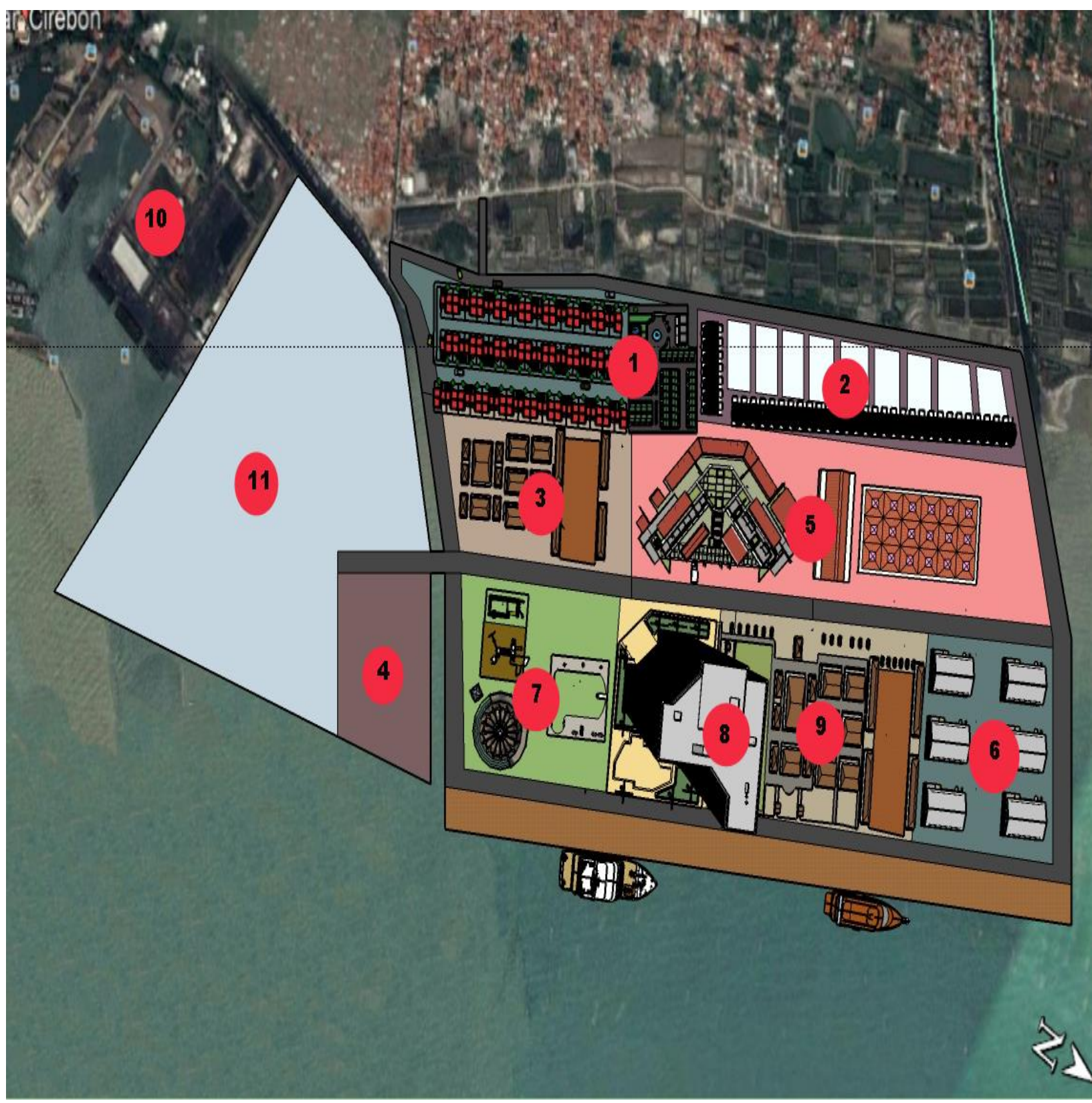

Gambar 5. Layout Pembangunan Waterfront City di Kota Cirebon

Keterangan:
(1) Permukiman nelayan
(7) Tempat Rekreasi
(2) Tambak udang
(8) Hotel/ RTH
(3) Tempat Pelelangan Ikan (TPI)
(9) Pusat kebudayaan
(4) Tempat pengolahan limbah mandiri
(10) Pelabuhan Cirebon
(5) Pasar
(11) Perluasan wilayah pelabuhan 
Faktor Exacta 11 (4): 385-398, 2018

p-ISSN: 1979-276X

e- ISSN: 2502-339X

DOI : 10.30998/faktorexacta.v11i4.2974

Triharto-Reklamasi Pesisir Kota Cirebon.....

(6) Pusat pengolahan ikan

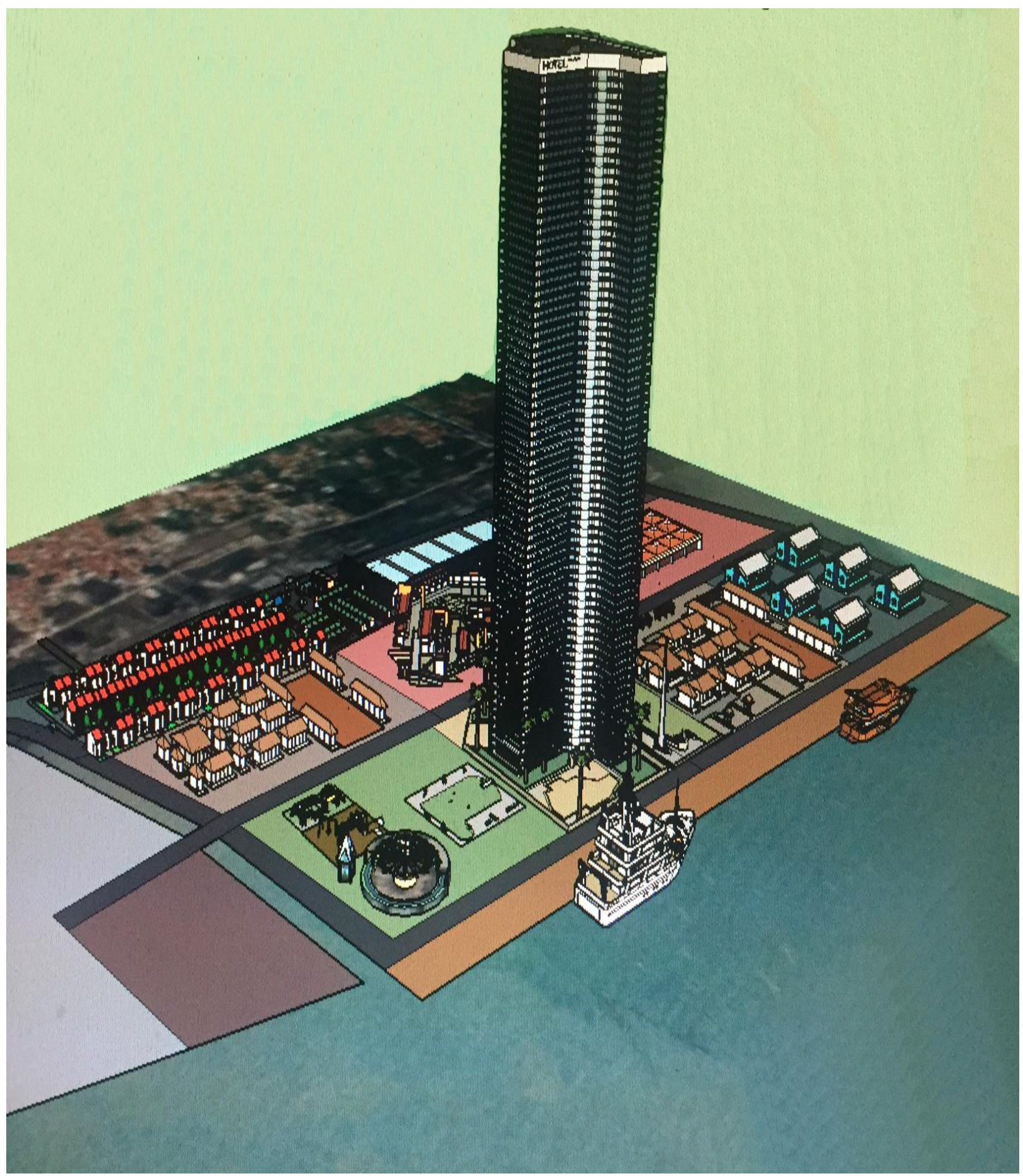

Gambar 6. Detail Pembangunan Waterfront City di Kota Cirebon

Berikut ini adalah elemen perencanaan penataan pembangunan waterfront city Kota Cirebon

\section{Permukiman nelayan}


Pembangunan permukiman nelayan di dalam waterfront city ini menjadi solusi bagi pemerintah kota dalam mengatur tata permukiman yang kumuh sekaligus bisa menjadikan icon tersendiri dan penting pada waterfroncity. Permukiman juga dapat ditata dengan gaya arsitektur tardisional Cirebon yang menjadikan ciri budaya kedaerahan sebagai daya pikat wisata pada kawasan pesisir.

\section{Tambak udang}

Salah satu komoditi unggulan dan menjadi salah satu sumber pendapatan daerah terbesar adalah tambak udang. Dengan adanya tambak udang di waterfront city dapat meningkatkan efektifitas dalam produksi dan distribusi, karena waterfront city merupakan salah satu akses menuju pelabuhan sehingga mempermudah.

\section{Pusat kegiatan nelayan}

Kegiatan bongkar muat, alat tangkap ikan, perawatan jaring ikan, Tempat Pelelangan Ikan (TPI), dan lainnya, serta penyortiran hasil tangkapan laut. akan ditampung pada pusat kegiatan nelayan ini. Area ini sebagai pusat segala aktivitas para nelayan yang pergi dan datang melaut.

\section{Tempat pengolahan limbah mandiri}

Pembangun sebuah pengolahan limbah pada kawasan waterfront, merupakan usaha agar meminimalisir dampak negatif akibat aktivitas, sehingga limbah yang ada tidak langsung dibuang ke laut tetapi melalui kegiatan pengolahan limbah terlebih dahulu agar tidak mencemari kawasan pesisir pantai.

5. Pasar

Pusat ekonomi yang sangat penting dan menjanjikan bagi masyarakat pesisir itu sendiri adalah pasar. Aktivitas kegiatan jual beli hasil olahan laut, hasil tambak, baik hasil laut dan hasil kreatifitas berupa cinderamata masyarakat pesisir pun terjadi disini.

6. Tempat pengolahan hasil laut

Pembangunan tempat pengolahan hasil laut yang terhubung langsung dangan pusat kegiatan nelayan dan pemasaran dapat mengoptimalkan produktifitas pengrajin yang akan berpengaruh kepada perekonomian dan taraf kehidupan masyarakat pesisir itu sendiri. Hasil olahan laut yang berupa terasi merupakan salah satu produk sektor unggulan yang dimiliki kota Cirebon.

\section{Tempat rekreasi}

Tempat rekreasi pantai berada di ujung waterfront dekat perairan, akan menjadi salah satu daya tarik bagi wisatawan. sebagai pelengkap tempat rekreasi yang ada saat ini dipesisir dengan di tunjang oleh panggung pertunjukan dan icon kota Cirebon sehingga menjadi objek wisata baru yang sangat menjanjikan.

\section{Hotel}

Begitu juga dengan dihadirkannya hotel sebagai penunjang wisatawan yang datang kepesisir Kota Cirebon untuk menikmati indahnya pesisir dan bermalam di wilayah pesisir.

9. Pusat kebudayaan

Kota Cirebon memiliki kebudayaan yang sangat banyak salah satu daya tarik terkuat bagi wisatawan adalah batik trusmi karena khas motifnya. Pembangunan pusat kebudayaan di waterfront city dapat menjadi satu anjang promosi untuk kota Cirebon itu sendiri, terlebih di bidang budaya dan pariwisatanya.

10. Ruang terbuka hijau

Kawasan yang terbuka dan hijau berfungsi sebagai tempat parkir dan assembly point jika terjadi suatu keadaan mendesak juga sebagai penunjang ruang terbuka hijau dari Pembangunan pusat ekonomi, sentra kebudayaan, rekreasi dan di dalam waterfront city. 


\section{PENUTUP}

\section{SIMPULAN}

Dari hasil analisis data serta analisis terhadap lokasi kawasan pesisir Kota Cirebon,dapat disimpulkan bahwa permasalahan kawasan pesisir di kota Cirebon adalah wilayah administrasi yang terbatas/kecil, tidak meratanya persebaran penduduk, potensi SDA (sumber daya alam) belum dikembangkan dengan baik, kondisi pesisir pantai yang mengalami abrasi dan sendimentasi tanpa pengelolaan yang tepat serta tumpang tindihnya pembangunan menambah rusaknya kondisi fisik kawasan pesisir yang mengancam keberlanjutan kehidupan penduduk pesisir, serta pembangunan prasarana dan sarana yang tidak tertata dengan baik dan sangat minim dikawasan pesisir Kota Cirebon. Maka diperlukan keterpaduan dan koordinasi dalam penataan yang saling terintegrasi dan menunjang dalam kawasan pesisir Kota Cirebon, oleh sebab itu dengan kondisi tersebut dan terbatasnya lahan maka diperlukan pembangunan waterfront city atau kawasan tepi air di kawasan pesisir yang berkelanjutan dengan cara reklamasi terutama pada bagian kawasan yang abrasi dan tersendimentasi yang terjadi secara alami, dan ulah masyarakat yang menimbun sampah kota di area kawasan pesisir.Diharapkan dengan adanya reklamasi dan diatasnya dibangun waterfront city menjadi solusi pemecahan masalah kawasan pesisir Kota Cirebon dalam pembangunan berkelanjutan juga sebagai pintu masuk kedua melalui laut. Waterfront city juga harus dilindungi oleh breakwater dilepas pantai, begitu juga pada muara sungai dibangun jetty.

\section{SARAN}

Dengan keterbatasan lahan dan beberapa permasalahan di kawasan pesisir salah satunya adalah abrasi, maka sebaiknya dilakukan pembangunan waterfront city atau kawasan tepi air dengan reklamasi, namun hendaknya perlu mengkajian terlebih dahulu data lebih akurat terkait pola sedimentasi, pola gelombang di kawasan pesisir, serta data-data perairan lainnya yang terkait. Hal ini diperlukan untuk memproteksi kawasan reklamasi yang akan dibangun waterfront city tersebut di atasnya. Selain itu, perencanaan sebaiknya memperhatikan hubungan, pola dan struktur kota Cirebon dan perencanaan waterfront city /tepi laut pesisir Kota Cirebon.

\section{DAFTAR PUSTAKA}

Bappeda Kota Cirebon. 2011-2031. RUTR Wilayah Kota Cirebon. Bappeda. Cirebon

Becker, E. 1997. Sustainable: A Cross-Disciplinary Concept for Social Transformations. Management Of Social Transformation (MOST). Policy Papers 6. Paris. UNESCO.

BPS Kota Cirebon. 2014. Cirebon Dalam Angka 2014. Bappeda Dan BPS Cirebon. Cirebon

Herdianto, WK. 2006. Analisis Manfaat Biaya Reklamasi Pantura Jakarta, Jurnal Lingkungan Vol. I/I 2006 hal. 14-19, PSIL-UI.Jakarta

Karyadi Kusliansjah, Adam Ramadhan. 2012. Struktur Pesisir (waterfront) Kota Cirebon - Jawa Barat, Laporan Hasil Penelitian Arsitektur Kota, Universitas Katolik Parahyangan, Bandung.

Lukita Purnamasari. 2009. Pengelolaan Wilayah Pesisir Secara Terpadu Dan Berkelanjutan Yang Berbasis Masyarakat, Jurnal Lingkungan Hidup, November.

Profil Kota Cirebon. 2016. Kerjasama Badan Perencana Pembangunan Daerah (BAPPEDA) dengan Badan Pusat Statistik Kota Cirebon.

Rencana Zonasi Wilayah Pesisir Dan Pulau-Pulau Kecil Provinsi Jawa barat Tahun 20132029.

Sidarta, Moch. 1996. Jakarta Waterfront City Development. Jurnal PWK, Vol.7, 38-45. 
Faktor Exacta 11 (4): 385-398, 2018

p-ISSN: 1979-276X

e- ISSN: 2502-339X

DOI : 10.30998/faktorexacta.v11i4.2974

Triharto-Reklamasi Pesisir Kota Cirebon.....

Sugandi, Aca. 1999. Penataan Ruang dalam Pengelolaan Lingkungan Hidup, Gramedia: Jakarta 